J. Perinat. Med.

2 (1974) 130

\section{A rapid procedure for testing the integrity of the maternal- fetal barrier in spontaneously delivered placentas}

\author{
H. Lemtis, H. Kirchner \\ Department of Obstetrics and Gynecology \\ Klinikum Steglitz of The Free University of Berlin \\ (Director: Professor Dr. G. Hörmann)
}

Received February 27, 1974. Accepted April 25, 1974.
The study of the maternal-fetal passage of drugs and other alien substances, particularly those of potentially hazardous substances of the occupational environment (with quantitative determinations in the blood of the fetal side of the placental vascular system) is an important consideration of perinatal medicine. Therefore, numerous authors (reviews by LemTis [18], GAGEL [5], and KirCHNER [10]) have attempted with their contributions to solve the difficult problem of the physiologically correct perfusion of the placenta. In spite of remarkable advances in the field, the bilateral long-term in vitro perfusion of the human placenta has not yet been accomplished satisfactorily. In part this is due to the failure of systematically studying the potential interferences occurring during perfusion with blood. On the other hand, investigators may have been impeded in their study by the uncertainty as to whether the available placenta was injured or intact. Over several years we have developed in collaboration with GAGEL and following the experimental designs of KRANTZ and coworkers [14, 15, 4, 8, 9, 13] Nesbitt et al. [21], as well as Hamrin et al. [7] a modern apparatus equipped for the bilateral long-term perfusion of spontaneously delivered human placentas [20], stressing the study of both the most favorable experimental conditions as well as possible interfering factors (see also Kirchner and Lemiss [11, 12]. During these experiments we designed a test which enables us to determine before the initiation of

\section{Curriculum vitae}

Horst GÜNTHER LEMTIS was born in 1923. He studied Medicine and Science at the University of Hamiburg and Kiel and obtained bis M. D. degree in 1954 at Kiel. Following bis residency in Obstetrics and Gynecology at the Universities of Marburg and Göttingen, be was appointed to the senior staff of the Second Obstetric-Gynecology Service of the Free University, Berlin, in 1963.

University lecturer 1967; Professor and Head of the Section of Experimental Gynecology at the Department of Obstetrics and Gynecology of the Klinilum Steglitz of the Free University, Berlin since 1969.

a lengthy perfusion experiment within a few minutes whether the maternal-fetal barrier of the experimental placenta is intact.

\section{Methods}

We started with the basic assumption that with a defective maternal-fetal barrier any dye present in the fetal vascular system should be transmitted very rapidly into the maternal placental circulation because of the pressure gradient from $80-90 \mathrm{~mm} \mathrm{Hg}$ in the fetal-placental to 10 to $20 \mathrm{~mm} \mathrm{Hg}$ in the maternal intervillous capillary system [23, 1, 3]. For this purpose, every ex- 
perimental placenta was placed in the "artificial" uterus of our experimental apparatus [20]. The fetal vessels were filled with warm normal saline solution and $2 \mathrm{ml}$ aliquots of a $0.2 \%$ solution of Evans Blue were injected at 2 minute intervals into the fetal placental circulation. The possible transplacental passage of the dye was registered photo-electrically at the location of the main drainage ("Collecting vein") of the maternal blood from the placenta in the artificial uterus. To this end our previously described experimental design was augmented by a universal oximeter. The dye concentration of the circulating fluid was measured with an ear electrode by the transmission principle. The resulting dye dilution curve was recorded simultaneously with the perfusion pressure and the minute volume continuously throughout the entire experiment on a compensation linear recorder. The choice of various sensitivities allowed the recording of even minute changes in the variables. A continuously adjustable bridge circuit allowed the adjustment of the units of measure of the apparatus to the circulating fluid of the individual experiments.

BLEYL [2] had demonstrated that the fetal-maternal barrier is always penetrated after a substantial increase of the perfusion pressure. This fact was of great importance for our experiments. Therefore, it was attempted to determine the limit of intravascular fetal placental pressure at which fetal maternal passage of a dye occurs. Since according to the findings of GAUER [6] pressure and minute volume are directly dependent on each other analogous to OHM's law, we increased the intravascular pressure by increasing the volume simultaneously with the Evans Blue injections at 2 minute intervals.

\section{Material}

The placentas used for establishing the technique had been delivered spontaneously from healthy mothers after normal pregnancies and showed no gross injuries. Each placenta was prepared for the experiment immediately after birth.

\section{Results}

Tab. I demonstrates the correlation between the passage of dye from the fetal into the maternal placental circulation and perfusion pressure and thus simultaneously from the volume. Damaged placentas had a passage of Evans Blue at the initial pressure of $50 \mathrm{~mm} \mathrm{Hg}$. Thus the barrier between the two vascular systems in these

Tab. I. Correlation between fetal-maternal passage of Evans Blue and fetal-placental intravascular pressure. The increase in pressure was accomplished by increasing the minute volume. The passage of dye occurred at bold face values.

\begin{tabular}{|c|c|c|c|c|c|c|c|c|c|c|c|}
\hline $\begin{array}{c}\text { Placenta } \\
\text { no. }\end{array}$ & $\begin{array}{l}\text { Pressure } \\
\text { increase } \\
(\mathrm{mm} \mathrm{Hg})\end{array}$ & 50 & 60 & 70 & 80 & 90 & 100 & 120 & 140 & 160 & Remarks \\
\hline 1 & \multirow{14}{*}{ 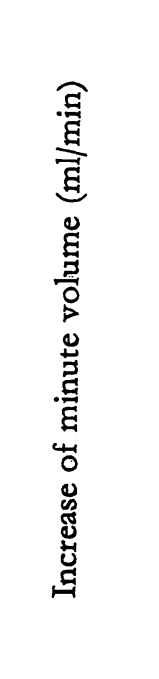 } & 30 & 35 & 40 & 45 & 70 & 75 & 95 & 120 & 150 & \multirow{14}{*}{$\begin{array}{r}\text { placenta } \\
\text { defective } \\
\text { placenta } \\
\text { defective }\end{array}$} \\
\hline 2 & & 30 & 45 & 55 & 60 & 75 & 120 & 125 & 140 & 145 & \\
\hline 3 & & 25 & 30 & 35 & 50 & 60 & 85 & 90 & 105 & 135 & \\
\hline 4 & & 20 & 25 & 35 & 45 & 50 & 80 & 115 & 130 & 150 & \\
\hline 5 & & 35 & 40 & 45 & 70 & 90 & 125 & 130 & 145 & 160 & \\
\hline 6 & & 30 & 35 & 40 & 65 & 80 & 95 & 100 & 115 & 120 & \\
\hline 7 & & 25 & 35 & 50 & 55 & 60 & 80 & 95 & 110 & 125 & \\
\hline 8 & & 40 & 45 & 65 & 70 & 85 & 100 & 115 & 130 & 145 & \\
\hline 9 & & 30 & 40 & 45 & 50 & 70 & 75 & 90 & 110 & 135 & \\
\hline 10 & & 30 & 35 & 40 & 60 & 80 & 90 & 100 & 125 & 140 & \\
\hline 11 & & 30 & 35 & 40 & 80 & 95 & 100 & 115 & 140 & 155 & \\
\hline 12 & & 25 & 30 & 40 & 50 & 60 & 80 & 100 & 110 & 120 & \\
\hline 13 & & 20 & 30 & 45 & 55 & 70 & 100 & 105 & 120 & 135 & \\
\hline 14 & & 25 & 30 & 40 & 50 & 65 & 70 & 95 & 105 & 130 & \\
\hline
\end{tabular}


placentas was defect. In intact placentas the passage of the dye occurred only after a pressure rise to $100-160 \mathrm{~mm} \mathrm{Hg}$ (see Tab. II). Figs. 1 and 2 demonstrate the difference between a placenta with intact and one with defective maternal-fetal barrier.

Tab. II. Pressure and minute volumes at which fetalmaternal dye passage occurred in intact placentas. $\mathrm{S}(\mathrm{x})=$ sum of all measurements; $\overline{\mathrm{x}}=$ arithmetic mean.

\begin{tabular}{ccc}
\hline & $\begin{array}{c}\text { Pressure } \\
(\mathrm{mm} \mathrm{Hg})\end{array}$ & $\begin{array}{c}\text { Minute volume } \\
\mathrm{ml} / \mathrm{min}\end{array}$ \\
\hline $\mathrm{S}(\mathrm{x})$ & 1300 & 1165 \\
$\overline{\mathrm{x}}$ & 118.2 & 105.9 \\
median & 120 & 105 \\
$80 \%$ range & $100-140$ & $80-120$ \\
\hline
\end{tabular}

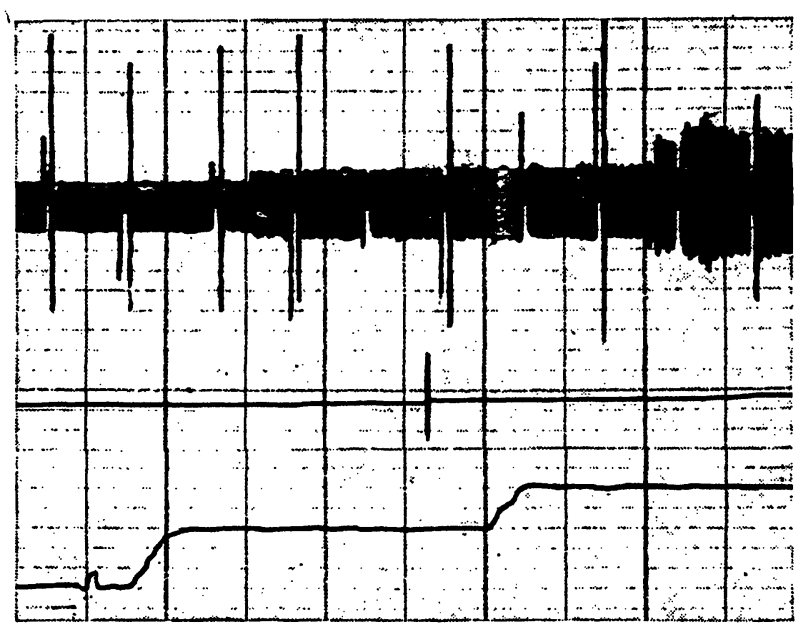

Fig. 1. Intact placenta. Dye dilution curve of Evans Blue (below) which has been injected at two-minute intervals into the fetal placental vascular system simultaneously increasing the intravascular pressure. Above: the recording of intravascular pressure, middle: registration of minute volume.

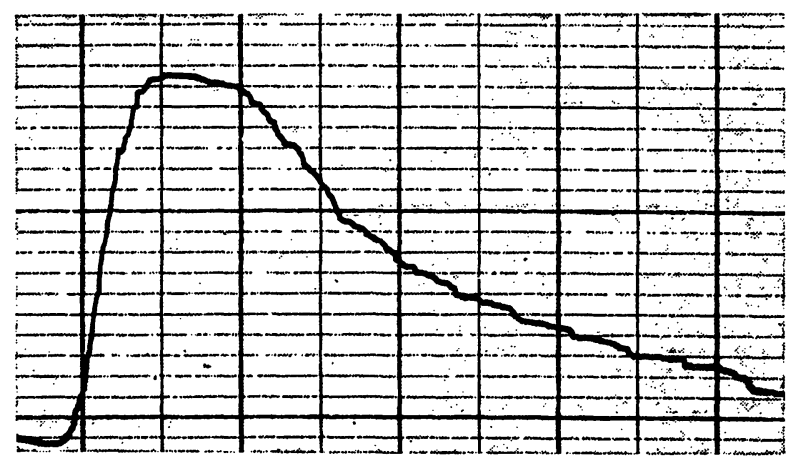

Fig. 2. Placenta with defective maternal-fetal barrier. Dye dilution curve following injection of Evans Blue into the fetal placental vascular system recorded photo-electrically at the "main vein" of the maternal placental circulation.

\section{Discussion}

In the great majority of the placentas with intact maternal-fetal barrier which we have examined, the passage of Evans Blue from the fetal into the maternal circulation occurred only with unphysiologic high intravascular pressures at a mean of $120 \mathrm{~mm} \mathrm{Hg}$ (see Tabs. I and II). Since both vascular systems were closed, the injected dye remained constantly in the fetal placental circulation with pressures under $100 \mathrm{~mm}$ $\mathrm{Hg}$. Because the oximeter was not recalibrated to zero following the injections of Evans Blue at 2 minute intervals, the curve must demonstrate a step-wise rise (Fig. 1).

Completely different results were found in placentas with a defective maternal-fetal barrier. Passage of dye from the fetal into the maternal circulation occurred already at the lowest initial pressures at the beginning of the experiments. The graphic depiction of the extinction curve shows a typical dye dilution curve (Fig. 2). Because the curves of an intact and a defective placenta are distinctly different from each other and the brief experiment can be carried out very quickly, it is ideally suited for testing the maternal-fetal barrier for its integrity. With the aid of this test we were able to demonstrate [19] that contrary to some assumptions only $30 \%$ of the spontaneously delivered placentas have a defective maternal-fetal barrier.

As demonstrated in Tabs. I and II the pressure limit at which even placentas with intact maternalfetal barrier will always have a dye passage from the fetal into the maternal placental circulation ranges from $100-160 \mathrm{~mm} \mathrm{Hg}$. Possibly each placenta has its own threshold regarding this "opening pressure". Apparently, in each placenta stomata in the area of the maternal-fetal barrier are opened when the individual "maximal pressure" is reached. These gaps in the capillary walls in the fetal-placental vacular system have been demonstrated by PANIGEL [22] after the existence of stomata had been suspected by us since the experiments of BLEYL [2]. This author had utilized the wash-out technique described by us in 1952 [16] and 1955 [17] and had successfully accomplished a complete exsanguination of placentas if following the introduction of glass 
cannulas into the umbilical arteries and closure of the umbilical vein, the placentas were perfused with pressures of over $100 \mathrm{~mm} \mathrm{Hg}$. Thus he had unknowingly proven that with sufficient, i. e. abnormally high, intravascular pressure, all components of blood may pass through certain gaps in the capillary walls of the fetal vascular system which are not normally open.

\section{Summary}

In the course of several years we developed in collaboration with GAGEL based on three American models a modern apparatus for the bilateral long-term perfusion of normally born human placentas, stressing the study of favorable experimental conditions as well as that of possible interfering factors. Because the bilateral long-term perfusion of placentas with blood is costly, it should be ascertained that a planned experiment is worthwhile (i. e. that the experimental placenta is intact). Thus far no practical experimental design had been described. The authors have now developed a test allowing to determine within

a few minutes before the initiation of a lengthy experiment whether the maternal-fetal barrier is defective. To this end the fetal vascular system of the placenta placed in the "artificial" uterus is filled with warm normal saline solution to which Evans Blue is added. With a small photo-electric attachment at the "collecting vein" of the maternal circulation similarly filled with normal saline it can be determined immediately whether the placenta in question is damaged. Normally the maternalfetal barrier is not passed by Evans Bluc. The test detected even minute defects.

Keywords: Diaplacental passage, dye passage (transplacental), maternal-fetal barrier, penetration, permeability, placental passage, placental perfusion, rapid placental test.

\section{Zusammenfassung}

Ein Schnelltest zur Prüfung der Mutter-Kind-Schranke spontan geborener Plazenten auf Unversehrtheit.

Im Verlaufe mehrerer Jahre wurde gemeinsam mit GAGEL in Anlehnung an 3 amerikanische Modelle eine mit modernsten Geräten ausgestattete Anlage zur beidseitigen Dauerperfusion geborener menschlicher Plazenten entwickelt, wobei auf das Studium der günstigsten Versuchsbedingungen sowie der möglichen Störfaktoren besonderer Wert gelegt wurde. - $\mathrm{Da}$ die doppelseitige Dauerperfusion von Plazenten mit Blut sehr kostpielig ist, muß gesichert sein, daß ein geplantes Experiment auch lohnt, d. h. daß der zu untersuchende Mutterkuchen intakt ist. Hierzu gab es bisher noch keine in der Praxis bewährte Versuchsanordnung. Dịe Autoren entwickelten jetzt einen Test, der es gestattet, vor Beginn eines großen

Experiments innerhalb weniger Minuten festzustellen, ob die Mutter-Kind-Schranke defekt ist. Dazu wird der fetale Gefäßapparat der in den ,,künstlichen“ Uterus eingebrachten Plazenta lediglich mit temperierter physiologischer Kochsalzlösung aufgefüllt, der Evans Blue zugesetzt wird. Mittels einer kleinen photoelektrischen Vorrichtung läßt sich dann an der ,Sammelvene“ des ebenfalls mit Kochsalzlösung beschickten mütterlichen Kreislaufs der Plazenta sofort feststellen, ob der Farbstoff aus den feto-plazentaren Strombahnen übergetreten ist, $d . h$. ob der betreffende Mutterkuchen verletzt ist. Normalerweise wird die Mutter-Kind-Schranke vom Evans Blue nicht passiert. Mit dem Test werden selbst kleinste Defekte erfaßt.

Schlüsselwörter: Diaplazentare Passage, Farbstoffpassage (transplazentare), Mutter-Kind-Schranke, Penetration, Permeabilität, Plazentapasssage, Plazentaperfusion, Plazenta-Schnelltest.

\section{Résumé}

Un test rapide pour l'examen de l'état de la barrière mère-foetus dans les placentas humains nés spontanément.

Après plusieurs années d'études réalisées avec le concours de GAGEL et s'appuyant sur trois modèles américains, les auteurs du présent article ont mis au point un systeme doté d'appareils ultra-modernes pour perfusions continuées ambilatérales de placentas humains nés. Un soin particulier a été porté sur l'étude des conditions optimales d'expérimentation et des facteurs de troubles éventuels. La perfusion placentaire continue ambilatérale avec du sang étant très coûteuse, il faut lui garantir le

maximum de chance de succès, $c$. à. d. s'assurer au préalable que le placenta à examiner est intact. Or, il n'existait aucun test sût jusqu'à ce que les auteurs de cet article aient mis au point une méthode qui permet de détecter en quelques minutes avant l'intervention une défection éventuelle de la barrière mère-foetus. Pour cela, le système vasculaire foetal du placenta placé dans l'utérus «artificiel» est rempli d'une solution saline physiologique tempérée, additionnée de Bleu d'Evans. Au moyen d'un petit dispositif photo-électrique fixé sur la "veine principale» de la circulation maternelle du placenta remplie aussi de solution saline physiologique, il est alors possible d'ob- 
server immédiatement si le colorant a traversé la barrière placentaire entre les circulations maternelle et foetale, c. à. d. si le placenta maternel concerné comporte des lésions. Normalement en effet, le Bleu d'Evans ne franchit pas cette barrière entre la mère et le foetus. Le test permet d'enregistrer même les plus ṕotites lésions de la paroi des capillaires du foetus.

Mots-clés: Barrière mère-foetus, passage de colorant (transplacentaire), passage diaplacentaire, passage placentaire, pénétration, perfusion placentaire, perméabilité, test placentaire rapide.

\section{Bibliography}

[1] Alvarez, H., R. Caldeyro-Barcia: Contractility of the human uterus recorded by new methods. Surg. Gynec. Obstet. 91 (1950) 1

[2] Bleyl, U.: Die Plazenta im fluoreszenz-mikroskopischen Bilde. Med. Diss., Kiel 1961

[3] Caldeyro-Barcia, R., H. Alvarez, S. R. M. ReyNoLDs: A better understanding of uterine contractility through simultaneous recording with an internal and a seven channel external method. Surg. Gynec. Obstet. 90 (1950) 641

[4] Christ, R. D., K. E. Krantz, J. C. Warren: Placental transfer of synthetic progestins. Obstet. and Gynec. 25 (1965) 89

[5] GAGEL, R.: Über einen „künstlichen“ Uterus als Grundlage für experimentelle Untersuchungen der Plazenta-Passage körpereigener und körperfremder Substanzen in vitro. Med. Diss., Berlin 1969

[6] Gauer, O. H.: Kreislauf des Blutes. In: RosemanN, H. U.: Lehrbuch der Physiologie des Menschen. 28. Aufl., Bd. I. Urban u. Schwarzenberg, München 1960

[7] Hamrin, C. E., W. L. Conger, R. N. Lindstrom, R. W. Shier, P. V. Dilts: Placental perfusion device. Amer. J. Obstet. Gynec. 110 (1971) 422

[8] Hensleigh, P. A., K. E. Krantz: Extracorporeal perfusion of the human placenta. I. Placental transfer of ascorbic acid. Amer. J. Obstet. Gynec. 96 (1966) 5

[9] Howard, J. M., K. E. Krant': Transfer and use of glucose in the human placenta during in vitro perfusion and the associated effects of oxytocin and papaverine. Amer. J. Obstet. Gynec. 98 (1967) 445

[10] KIRChNER, H.: Die doppelseitige Dauerperfusion der menschlichen Plazenta in vitro und ihre Störmöglichkeiten. Med. Diss., Berlin 1972

[11] Kirchner, H., H. Lemtis: Über einige Vorbedingungen zur Untersuchung der Mutter-Kind-Schranke in vitro. In: Saling, E., J. W. Dudenhausen: Perinatale Medizin, Bd. III, 4. Deutscher Kongreß für Perinatale Medizin,-Berlin 1971. Thieme, Stuttgart 1972

[12] Kirchner, H., H. Lemtis: Über die Vorbedingungen zur Untersuchung der Plazenta-Passage auf Pharmaka und gesundheitsschädliche Stoffe in vitro. Lecture Ges. Geburtsh. Gynäk. in Berlin, session on January 12, 1973. Geburtsh. u. Frauenheilk. (in press)

This work is dedicated to Professor HöRMANN on the occasion of his sixtieth birthday.
[13] Krantz, K. E., J. Blakey, K. Yoshida, J. A. Romrto: Demonstration of viability of perfused human term placenta. Obstet. and Gynec. 37 (1971) 183

[14] Krantz, K. E., T. C. Panos: Apparatus for establishment of separate extracorporeal fetal and maternal circulation in the human placenta. J. Dis. Child. 98 (1959) 674

[15] Krantz, K. E., T. C. Panos, J. Evans: Physiology of maternal-fetal relationships through the extracorporeal circulation of the human placenta. Amer. J. Obstet. Gynec. 83 (1962) 1214 (with discussion)

[16] Lemtrs, H.: Ein Beitrag zur normalen Anatomie der menschlichen Plazenta: Ergebnisse experimenteller Studien über die Architektonik des plazentaren $\mathrm{Ge}$ fäßapparates. Med. Diss., Kiel 1952

[17] Lemtrs, H.: Über die Architektonik des Zottengefäßapparates der menschlichen Plazenta. Anat. Anz. 102 (1955) 106

[18] Lemtis, H.: Über die Blutströmung im intervillösen Kapillarsystem der menschlichen Plazenta. Habilitationsschrift, Berlin 1966

[19] Lemtrs, H., H. KIRChNeR: Über die Häufigkeit von Spontanverletzungen des Mutterkuchens unter der Geburt. Arch. Gynäk. 214 (1973) 325

[20] Lemtis, H., H. KirchneR, R. GAGEL: Die beidseitige Dauerperfusion menschlicher Plazenten in vitro. Arch. Gynäk. (in press)

[21] Nesbitt, R. E. L., P. A. Rice, J. E. Rourke, V. F. Torresi, A. M. SouchaY: In vitro perfusion studies of the human placenta. A newly-designed apparatus for extracorporeal perfusion achieving dual closed circulation. Gynec. Invest. 1 (1970) 185

[22] Paniger, M.: Comparative anatomical, physiological and pharmacological aspects of placental permeability and haemodynamics in the non-human primate placenta and in the isolated perfused human placenta. In: Pecrle, A., C. Finzr: The foeto-placental unit. Excerpta Medica Foundation, Amsterdam 1969

[23] Woodbury, R. A., W. F. Hamition, R. Torpin: The relationship between abdominal, uterine and arterial pressures during labor. Amer. J. Physiol. 121 (1938) 640

Prof. Dr. med. H. Lemtis

Frauenklinik im Klinikum Steglitz

der Freien Universität Berlin

Hindenburgdamm 30

D-1000 Berlin 45/Germany 